\title{
Analisis Studi Kelayakan Bisnis Usaha Ikan Hias Lokal Khas Bangka Belitung Di Wilayah Kota Pangkalpinang (Tahun 2020-2021)
}

\author{
Dewi Ratnasari ${ }^{1}$, Nelly Astuti ${ }^{2}$, Rizal R. Manullang ${ }^{3}$ \\ 1STIE-IBEK Pangkalpinang, dewiratnas795@gmail.com \\ 2STIE-IBEK Pangkalpinang, nellyastuti39@gmail.com \\ ${ }^{3}$ STIE-IBEK Pangkalpinang, rizal.ruben@stie-ibek.ac.id
}

\begin{abstract}
ABSTRAK
Tujuan dari kegiatan penelitian ini adalah (1) untuk mengetahui kelayakan usaha usaha ikan hias lokal khas Bangka Belitung di wilayah kota Pangkalpinang. Metode yang digunakan dalam penelitian ini adalah metode deskriptif kualitatif dengan metode studi kasus, yaitu menggambarkan dan menggambarkan kondisi yang ada di lokasi penelitian pada saat observasi dilanjutkan dengan menganalisis permasalahan yang dihadapi dengan menggunakan analisis kelayakan usaha termasuk net present value (NPV). , Average rate of return (ARR), payback period (PP) dan profitabilitas index (PI) serta untuk melihat perkembangan strategi bisnis ikan hias lokal ini dengan menggunakan analisis SWOT dan melihat permintaan dan penawaran pasar, serta bauran pemasaran. Usaha ikan hias lokal yang dikaji berdasarkan hasil metode perhitungan NPV sebesar Rp34.165.964, hasil metode perhitungan ARR sebesar 92\%, dan hasil metode perhitungan PP mampu mengembalikan modal selama 8 bulan, maka metode perhitungan PI sebesar 2,36. Bisnis ini sangat layak untuk dijalankan.
\end{abstract}

Kata kunci : studi kelayakan usaha, ikan hias lokal.

\section{ABSTRACT}

The objectives of this research activity are (1) to determine the business feasibility of a local ornamental fish business typical of Bangka Belitung in the Pangkalpinang city area. The method used in this study is a qualitative descriptive method with a case study method, which describes and describes the conditions that existed at the research location at the time of observation followed by analyzing problems encountered using business feasibility analysis including net present value (NPV), Average rate of return $(A R R)$, payback period $(P P)$ and profitability index $(P I)$ and to see the development of this local ornamental fish business strategy by using SWOT analysis and looking at market demand and supply, as well as the marketing mix. The local ornamental fish business studied was based on the results of the NPV calculation method of Rp.34,165,964, the results of the ARR calculation method of $92 \%$, and the results of the PP calculation method being able to return capital for 8 months, then the PI calculation method of 2.36. This business is very feasible to run.

Keywords : business feasibility study, local ornamental fish.

\section{A. PENDAHULUAN}

Indonesia adalah salah satu negara agraris terbesar di dunia, dengan potensi sumber daya dan daya dukung ekosistem yang sangat besar. Indonesia dapat menghasilkan produk dan jasa dari sektor pertanian, perkebunan dan perikanan, dimana sector - sektor ini sangat memberikan dukungan penuh terhadap pembangunan dan perekonomian negara. Sektor perikanan memiliki potensi dan peranan penting bagi perekonomian Indonesia dilihat dari fungsinya sebagai penyedia bahan baku pendorong agroindustri, peningkatan devisa melalui ekspor hasil perikanan, menyediakan lapangan pekerjaan dan meningkatkan kelestarian sumber daya perikanan dan lingkungan hidup. Perikanan dan kelautan Indonesia memiliki potensi pembangunan ekonomi dan termasuk prospek bisnis yang cukup besar, sehingga dapat dijadikan sebagai sektor andalan untuk mengatasi krisis 
ekonomi.

Kepulauan Bangka Belitung merupakan sebuah provinsi yang dikelilingi oleh laut atau perairan terletak di antara pulau Sumatera dan pulau Kalimantan. Bangka Belitung juga memiliki pemandangan alam yang tak kalah cantik dari provinsi lain, selain itu Bangka Belitung juga memiliki beragam jenis ikan hias lokal dan endemik yang juga tak kalah cantik dari ikan hias dari daerah lain di Nusantara.

Keberagaman spesies ikan lokal dan endemik air tawar Bangka Belitung merupakan kekayaan hayati yang mempunyai nilai ekonomi secara langsung dan tidak langsung.Ikan yang ditemukan diperairan Bangka Belitung sangat beragam spesies dan jenis-jenisnya. Beberapa spesies ikan lokal yang ditemukan di perairan Bangka seperti spesies ikan snakehead atau biasa disebut chana, spesies cat fish, spesies barb, spesies loach, spesies rasbora, spesies gurami, spesies wild betta, spesies ikan payau dan spesies shrimp atau udang. Beragamnya jenis ikan yang ada di wilayah perairan pulau Bangka Belitung sangat memiliki potensi untuk nilai ekonomis baik dari sisi ikan hias ataupun ikan konsumsi. Seperti halnya di wilayah kota Pangkalpinang sudah banyak tersedia toko-toko ikan hias, namun tidak banyak yang memasarkan ikan hias lokal. Kebanyakan dari toko-toko ikan hias tersebut banyak menjual ikan hias dari luar pulau bahkan luar negeri yang diperbolehkan untuk dipasarkan. Karena ada beberapa jenis ikan yang memang tidak boleh dipasarkan karena dilindungi oleh Undang-Undang.

Ikan hias merupakan salah satu komoditas perikanan yang menjadi komoditas perdagangan yang potensial di dalam maupun di luar negeri. Ikan hias dapat dijadikan sumber pendapatan devisa bagi negara. Ikan hias memiliki daya tarik tersendiri untuk menarik minat para pecinta ikan hias dan juga kini banyak para pengusaha ikan konsumsi yang beralih pada usaha ikan hias. Kelebihan dari usaha ikan hias adalah dapat diusahakan dalam skala besar maupun kecil ataupun skala rumah tangga, selain itu perputaran modal usaha ini relatif cepat. Ikan hias lokal selain untuk hobi berpotensi menjadi lahan bisnis dengan adanya permintaan dan peluang bisnis untuk menjalani dan mengembangkan usaha ikan hias lokal khas Bangka Belitung baik dari sisi harga dan kualitas. Oleh sebab itu perlu dipelajari mengenai studi kelayakan bisnis ikan hias lokal khas Bangka Belitung dilihat dari beberapa aspek yang terkait dengan studi kelayakan, diantaranya dapat dipelajari dari aspek pasar dan pemasaran, aspek teknis dan aspek finansialnya untuk mengetahui layak atau tidaknya usaha ini untuk dijalankan.

\section{B. KAJIAN TEORI}

\section{Ikan Hias Lokal Khas Bangka Belitung}

Bangka Belitung memiliki beberapa jenis ikan hias lokal dan endemik. Hal ini juga diperkuat oleh beberapa jurnal tentang ikan lokal dan endemik, yang mana jenis-jenis ikan tersebut memang langka dan sudah jarang ditemukan didaerahdaerahnya, seperti ikan endemik Bangka Belitung. Menurut Ismu Sutanto Suwelo (2005), ikan-ikan hias lokal dan endemik di Nusantara yang tersebar dan terbagi dibeberapa pulau memang jarang dan terancam punah dan harus dilindungi oleh undang-undang. Oleh karenanya, usaha ikan hias lokal khas Bangka Belitung yang akan dijalani harus melihat ikan apa saja yang boleh dan tidak boleh untuk diperjualbelikan, dan ikan-ikan yang memang harus dibudidayakan agar tetap ada populasinya. 


\section{Aspek Pasar dan Pemasarannya}

Analisa aspek pasar dan pemasaran berfungsi dalam memahami seberapa besar potensi pasar yang dicapai, seberapa luas pasar yang dapat diraih oleh perusahaan, serta strategi pemasaran apa yang dapat direncanakan untuk mendapatkan konsumen di pasar (Husnan \& Muhammad, 2000).

Pengertian pasar pada kajian studi kelayakan bisnis harus diartikan secara luas, mengutip pendapat Stanton, pasar adalah orang-orang yang mempunyai keinginan untuk puas, uang untuk berbelanja dan kemauan untuk membelanjakannya.

Pada definisi yang disebutkan dapat diketahui adanya tiga unsur penting yang terdapat dalam pasar yaitu:

1. Orang dengan segala keinginannya

2. Daya mampu membeli barang

3. Kemauan untuk membelanjakan uangnya.

Dalam analisis pasar juga akan dilakukan analisis potensi pasar dan strategi yang digunakan untuk pemasaran produk. Strategi pemasaran produk yang akan digunakan dengan melakukan segmenting, targeting dan positioning, setelah mengetahui hal tersebut selanjutnya baru bisa disusun strategi bauran pemasaran yaitu 4P atau produk, harga, distribusi dan promosi. Analisis dalam aspek pasar juga bisa menggunakan metode analisis SWOT singkatan dari kata Strenght (kekuatan), Weakness (Kelemahan), Opportunities (peluang), Threats (ancaman).

Kegiatan yang paling penting dalam proses analisis SWOT adalah memahami seluruh informasi dalam suatu kasus, menganalisis situasi untuk mengetahui isu apa yang sedang terjadi dan memutuskan tindakan apa yang harus dilakukan untuk memecahkan masalah.

Dari pendapat di atas dapat disimpulkan bahwa analisis aspek pasar dan pemasaran dalam adalah analisis untuk melihat seberapa besar permintaan, penawaran dan peluang pasar serta strategi dalam mengembangkan usaha yang bisa menguntungkan dan berkelanjutan.

\section{Aspek Teknis}

Aspek teknis atau operasi juga dikenal sebagai aspek produksi. Hal-hal yang perlu diperhatikan dalam aspek teknis adalah pemilihan lokasi yang strategis, skala produksi yang optimal dan pemilihan produksi yang tepat, peralatan dan perlengkapan yang bagus, desain dan tata letak bangunan yang mumpuni, serta sarana prasarana dan teknologi yang digunakan bisa diterima dan dimanfaatkan secara maksimal.

Aspek teknis berkaitan dengan kegiatan pembangunan proyek baik secara teknis maupun pengorganisasiannya setelah proyek tersebut selesai dibangun (Husnan \& Muhammad, 2000).

\section{Studi Kelayakan Bisnis}

Studi kelayakan bisnis dapat dilakukan untuk menilai kelayakan investasi, baik pada suatu proyek maupun bisnis yang sedang berjalan. Studi kelayakan yang dilakukan untuk menilai kelayakan suatu proyek yang akan dijalankan disebut studi kelayakan proyek, sedangkan studi kelayakan yang dilakukan untuk menilai kelayakan dalam pengembangan suatu usaha disebut studi kelayakan bisnis. Pengertian studi kelayakan bisnis adalah suatu kegiatan yang mempelajari secara mendalam tentang suatu kegiatan atau usaha yang akan dijalankan, untuk menentukan layak atau tidaknya suatu bisnis yang dijalankan. 
Menurut Manulang (2020), mengungkapkan studi kelayakan bisnis sebagai studi mengenai rencana bisnis yang menganalisis layak atau tidak layak sebuah bisnis dibangun, dan juga saat dioperasikan secara rutin dalam rangka pencapaian keuntungan yang maksimal untuk waktu yang tidak ditentukan.

Selanjutnya, studi kelayakan bisnis adalah aktiitas dalam menilai manfaat yang diperoleh dalam melaksanakan suatu aktivitas bisnis atau proyek yang masih direncanakan.

Berdasarkan pengertian diatas, dapat disimpulkan bahwa studi kelayakan bisnis adalah sebuah studi atau penelitian yang berkaitan dengan analisa rencana pendirian bisnis apakah layak atau tidak untuk dilakukan. Layak atau tidaknya bisnis tersebut dijalankan dengan manfaat dan keuntungan yang akan timbul atau diperoleh dari bisnis tersebut.

Perhitungan dalam studi kelayakan bisnis menggunakan beberapa metode perhitungan, diantaranya adalah :

1. Net Present Value

merupakan metode yang dilakukan dengan cara membandingkan nilai sekarang dari aliran kas masuk bersih dengan nilai sekrarang dari biaya investasi.

2. Average Rate Of Return

merupakan metode yang digunakan untuk mengukur tingkat keuntungan yang diperoleh dari suatu investasi. Tingkat keuntungan yang digunakan dalam metode ini adalah laba setelah pajak dibandingkan dengan total atau rata-rata investasi.

3. Payback Periode

merupakan metode yang digunakan dalam menghitung tingkat pengembalian dalam investasi, PP adalah salah satu metode dalam menilai kelayakan usaha yang digunakan untuk mengukur periode waktu pengembalian modal yang digunakan.

4. Profitability Index

Metode PI merupakan metode yang menghitung perbandingan nilai antara nilai sekarang penerimaan kas bersih di masa yang akan datang dengan nilai sekarang investasi.

\section{GAMBAR KERANGKA PEMIKIRAN}

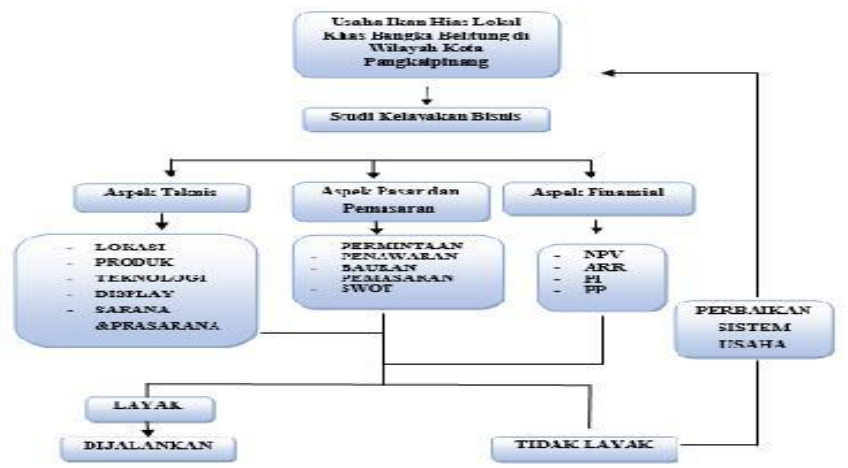

Sumber : Data Diolah Peneliti, 2021

\section{METODE PENELITIAN}

\section{Metode dan Desain Penelitian}

Menurut Sugiyono (2016), mengemukakan metode kualitatif sebagai prosedur 
penelitian yang menghasilkan data deskriptif berupa kata-kata atau lisan dari orangorang dan perilaku yang dapat diamati. Metode pada penelitian yang dilakukan menggunakan metode pendekatan deskriptif kualitatif yaitu untuk menjelaskan dan mendefinisikan tentang usaha ikan hias lokal khas Bangka Belitung melalui wawancara kepada beberapa pemilik atau narasumber tentang ikan hias lokal khas Bangka Belitung di kota Pangkalpinang, kemudian menghitung analisa pendapatan yang diperoleh dari usaha ini, selanjutnya pendapatan yang diperolehakan dihubungkan dengan analisis kelayakan bisnis dari aspek teknis, aspek pasar dan pemasaran denganmenggunakan metode analisis SWOT dengan melihat kondisi permintaan pasar, penawaran pasar dan strategi pemasaran yang ada dan juga dan aspek finansialnya dengan kriteria perhitungan NPV, ARR, PI, dan $\mathrm{PP}$, selanjutnya apabila hasil dari perhitungan yang diperoleh sesuai kriteria analisis kelayakan bisnis, maka usaha ikan hias lokal khas Bangka Belitung di wilayah kota Pangkalpinang layak untuk dijalankan.

\section{Tempat dan Waktu Penelitian}

Penelitian ini dilakukan di Perumahan Taman Semesta Mas No 82.JIn Fatmawati RT 010 RW 000 Kelurahan Tua Tunu Indah Kecamatan Gerunggang Kota Pangkalpinang Bangka Belitung.

\section{Populasi dan Sampel}

Sampel adalah bagian dari jumlah karakteristik yang dimiliki oleh populasi tersebut (Sugiyono, 2016). Sampel penelitian dilakukan dibeberapa toko ikan hias dikota Pangkalpinang, melalui proses observasi, wawancara dan dokumentasi dari beberapa toko ikan hias, ada 3 toko hias yang menjual ikan hias lokal khas Bangka Belitung diantaranya :

1. Toko Gale Gale Olshop

Beralamatkan di Perumahan Lega Vista IV Blok I No. 8 Kelurahan Jerambah Gantung Kecamatan Gabek Pangkalpinang. Pemilik Toko ikan hias ini bernama bapak Swarlanda

2. Toko Kopet Aquatic

Toko ikan ini beralamat kan di Jln Air Mawar, Gg Junai Kelurahan Air Mawar Kecamatan Bukit Intan Kota Pangkalpinang. Pemilik toko ini bernama bapak Azli

3. Toko King

Toko ikan King beralamatkan di Jln.Kurma No. 21 Kelurahan Air Kepala Tujuh Kecamatan Gerunggang Kota Pangkalpinang. Pemilik toko ikan hias ini bernama bapak Aziz.

\section{Sumber dan Teknik Pengumpulan Data}

Dalam penelitian ini sumber dan teknik pengumpulan data yang dilakukan oleh penulis adalah sebagai berikut:

1. Studi Kepustakaan (Study Research)

Sebuah penelitian tidak terlepas dari studi kepustakaan yang berdasarkan teori-teori yang sudah dikembangkan dan dipelajari oleh beberapa ahli dan penelitian terdahulu. Menurut Sugiyono (2016), studi pustaka adalah kajian teoritis, referensi serta literature ilmiah lainnya yang berkaitan dengan budaya, nilaidannorma yang berkembang pada situasi social atau lingkungan yang diteliti.

2. Studi Lapangan (Field Research)

Sunyoto (2015), mengatakan studi lapangan adalah suatu metode yang 
dilakukan oleh peneliti dengan cara pengamatan yang dilakukan oleh perusahaan. Langkah- langkah yang biasa dilakukan dalam studi lapangan antara lain :

a. Observasi

Menurut Nasution (2019), obserasi adalah pengamatan terhadap suatu objek yang diteliti baik secara langsung ataupun tidak langsung untuk memperoleh atau mengetahui data yang harus dikumpulkan dalam penelitian untuk mengetahui keberadaan objek,situasi dan kejadian penting dalam upaya mengumpulkan data penelitian. Maka penulis melakukan observasi langsung ke lapangan pada kegiatan atau aktivitas operasional yang terjadi sehubungan dengan keperluan data-data yang menjadi objek penelitian.

b. Wawancara

Menurut Nasution (2019), wawancara adalah bentuk komunikasi atau percakapan yang bertujuan untuk memperoleh data dan informasi dalam keadaan saling berhadapan atau melalui telepon. Wawancara ditujukan kepada pemilik usaha atau bagian manajemen dari sebuah perusahaan yang menjadi objek penelitian. Hasil dari wawancara penulisakan memperoleh data mengenai gambaran umum dan sejarah berdiri dan berkembangnya usaha atau perusahaan.

\section{Teknik Analisis Data}

Teknik analisis data yang dilakukan dalam penelitian usaha ikan hias lokal khas Bangka Belitung di wilayah kota Pangkalpinang ini adalah teknik analisis yang berkaitan dengan kriteria studi kelayakan bisnis, diantaranya meliputi :

1. Aspek Pasar dan Pemasaran

Analisis SWOT dilihat dari beberapa sisi yang saling berhubungan dan saling mempengaruhi.
a. Peluang dan Kekuatan
b. Kekuatan dan Ancaman
c. Ancaman dan Kelemahan
d. Kelemahan dan Peluang.

Pada aspek pasar juga mempelajari tentang strategi pasar diantaranya :

a. Permintaan Pasar (Jumlah permintaan)

b. Penawaran

c. Pasar (Jumlah penawaran)

d. Pemasaran (Marketing mix - $4 \mathrm{P}$ )

e. Pendapatan.

2. Aspek Teknis

Aspek teknis yang dilakukan dalam usaha ikan hias local khas Bangka Belitung di wilayah kota Pangkalpinang adalah :
a. Lokasi yang strategis
b. Skala produk dan produksi yang Optimal
c. Teknologi yang digunakan
d. Desainbangunan
e. Sarana dan prasarana.

3. Aspek Keuangan

Aspek finansial atau keuangan dalam usaha ikan hias lokal in idapat dihitung berdasarkan kriteria kelayakan bisnis, antara lain :

a. Net Present Value (NPV) 

b. Average Rate Of Return (ARR)
c. Payback Period (PP)
d. Profitability Index (PI)

\section{HASIL DAN PEMBAHASAN}

\section{Analisis Kelayakan Non Finansial Analisis Aspek Pasar dan Pemasaran}

Analisa aspek pasar menggunakan metode analisis SWOT, ditinjau dari beberapa sisi yaitu kekuatan, kelemahan, peluang dan ancaman. Oleh karenanya metode analisis SWOT dalam aspek pasar dan pemasaran dalam usaha ikan hias lokal ini sangat penting juga dilakukan agar mampu mengatasi masalah yang akan dihadapi dan merealisasikan dan menjalankan peluang-peluang yang ada. Dalam metode analisis SWOT tidak jauh berbeda dengan bauran pemasaran atau marketing mix, karena melihat dari sisi permintaan dan penawaran pasarnya pada analisis SWOT akan terlihat beberapa kemungkinan yang terjadi yang saling mempengaruhi dan berhubungan antara kekuatan dan kelemahan suatu usaha,serta peluang dan ancaman yang akan dihadapi. Seperti kuadran SWOT berikut :

\section{GAMBAR KUADRAN SWOT}

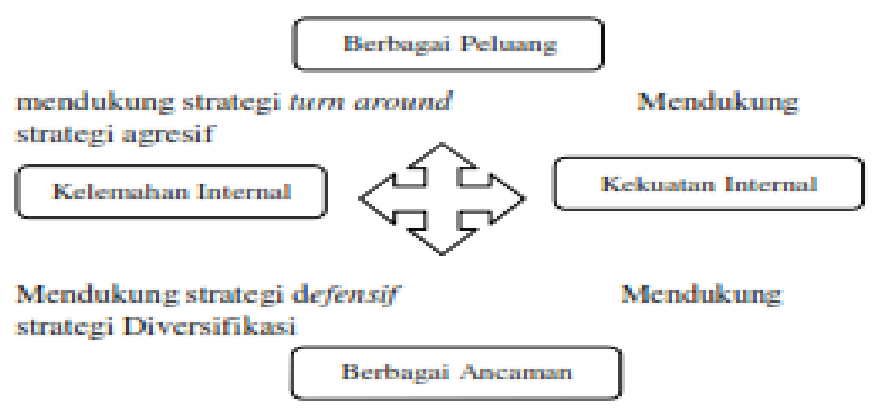

Sumber : (Rangkuti, 2015)

Analisis dalam aspek pasar bisa juga dilakukan pada beberapa poin penting yang bisa dilakukan dalam suatu usaha, diantaranya adalah melihat :

1. Permintaan Pasar

Permintaan pasar adalah melihat pada kondisi pasar seberapa banyak jumlah atau volume permintaan akan barang atau jasa yang dihasilkan oleh suatu usaha atau bisnis yang diperjualbelikan sesuai permintaan konsumen dengan harga tertentu dalam periode tertentu pula.

Pada usaha ikan hias lokal khas Bangka Belitung di wilayah kota Pangkalpinang, penulis mengambil sampel produk pada 3 toko dengan 30 jenis ikan hias lokal yang ada dan melihat pada toko-toko ikan hias yang memasarkannya ikan hias mana saja yang menjadi permintaan lebih banyak atau lebih dikenal oleh konsumen. Jumlah permintaan pasar yang sudah direkapitulasi dari 3 toko ikan yang memasarkan ikan hias lokal khas Bangka Belitung dapat dilihat pada grafik berikut.

GRAFIK PERMINTAAN PASAR IKAN HIAS LOKAL PADA 3 TOKO IKAN HIAS 


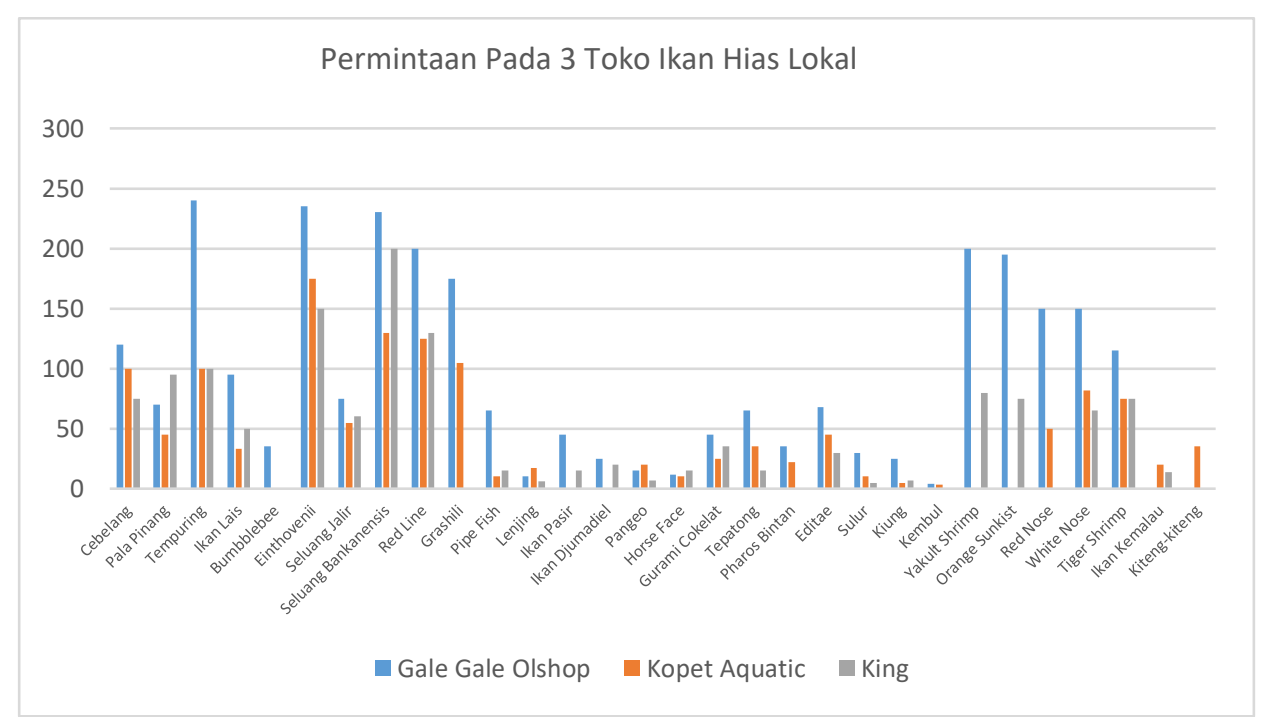

Sumber : Toko Ikan Hias Lokal Di Wilayah Kota Pangkalpinang, 2021

Total permintaan pasar akan ikan hias lokal khas Bangka Belitung dapat dilihat pada grafik berikut :

\section{GRAFIK TOTAL PERMINTAAN PASAR IKAN HIAS LOKAL PADA 3 TOKO IKAN HIAS}

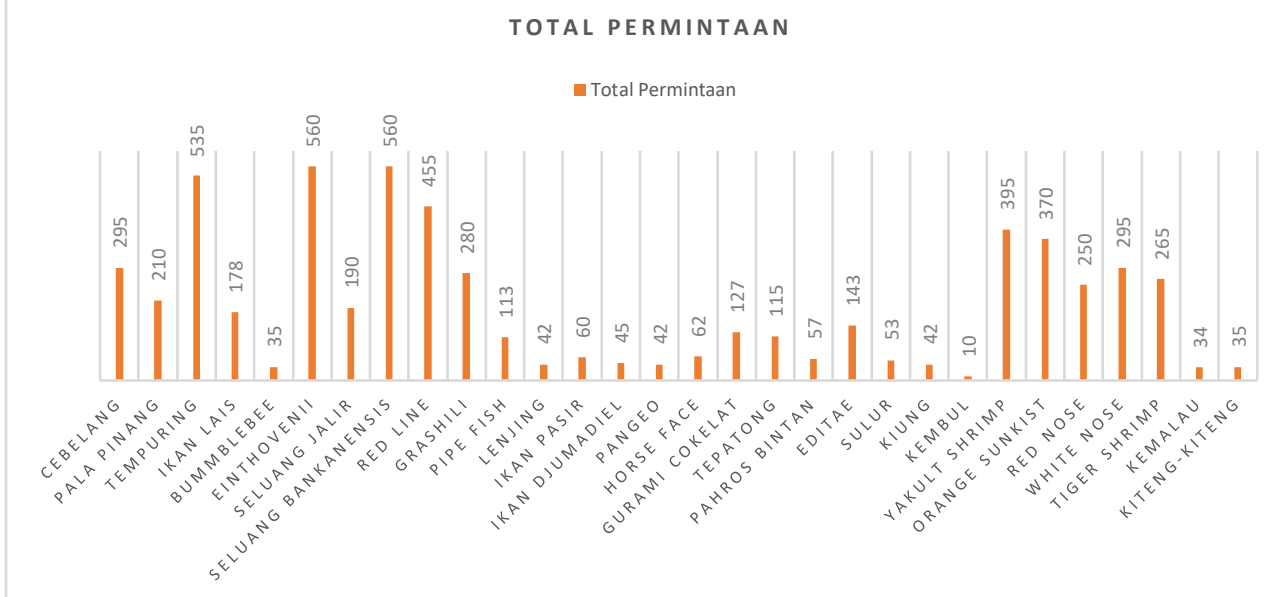

Sumber : Toko Ikan Hias Lokal Di Wilayah KotaPangkalpinang,2021

\section{Penawaran Pasar}

Produk yang berkualitas baik tidak terlepas juga dari harga yang sesuai dengan kualitasnya. Sebuah produk yang dihasilkan dengan hasil yang biasa saja, namun sebaliknya produk dengan kualitas yang baik tetap akan memiliki harga yang lebih tinggi. Pada dasarnya harga akan menentukan kualitas.

Ketiga toko diatas memberikan penawaran harga yang bervariasi pada 30 jenis ikan yang dipasarkan, dari toko-toko ikan hias ini juga terlihat perbedaan ketersediaan jenis ikannya, baik itu harga jual atau beli dari toko tersebut dalam membeli ikan dari pemasok ataupun menangkap langsung dari alamnya.

\section{Pemasaran}


Strategi pasar adalah salah satu strategi yang akan dan harus dijalankan dalam menjalankan suatu usaha dan mampu memenangkan persaingan secara sehat dan terbuka antar pengusaha. Dalam strategi pasar dapat dilihat dan teliti melalu bauran pemasaran atau marketing mix $4 \mathrm{P}$, yaitu :

\section{a. Product (Produk)}

Produk yang dipasarkan pada usaha ikan hias ini yang utama tentu saja jenisjenis ikan hias yang pada umumnya sudah dikenal oleh masyarakat namun ada juga dengan penyebutan nama yang berbeda disetiap daerahnya.Dari 30 jenis ikan hias lokal yang ditawarkan pada 3 toko ikan hias lokal yang menjadi sampel penelitian, ada 10 jenis ikan hias lokal yang permintaan pasarnya terbanyak.

\section{GRAFIK JENIS IKAN TERBANYAK MENURUT PERMINTAAN PASAR}

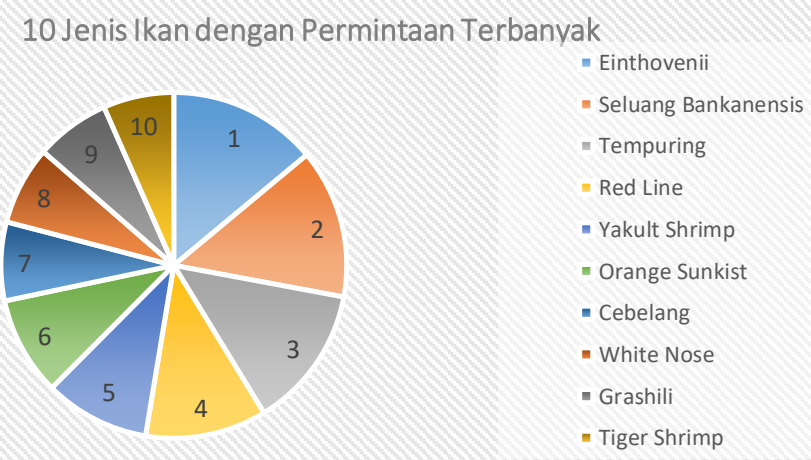

Sumber : Toko Ikan Hias Lokal di Wilayah Kota Pangkalpinang 2021

\section{b. Price ( Harga )}

Produk yang dipasarkan tidak terlepas dari harga yang sesuai dengan produknya, ada jenis ikan yang mudah dicari dan mudah dikembangbiakkan, adapula ikan yang susah didapat, atau pengembangbiakkan membutuhkan waktu yang lama, maka akan ditawarkan dengan harga-harga yang beragam tergantung dari jenis dan keunikan dari ikan hias itu sendiri. Harga ikan-ikan hias lokal dari 3 toko sebagai sampel penelitianjuga memiliki perbedaan dalam pemasarannya,harga ikan hias lokal dan harga ikan hias dari luar daerah pun memiliki perbedaan dan persamaan harga, dari kualitas produk baik dari bentuk, warna dan karakteristik ikanikannya. Berikut perbedaan harga jual ikan hias lokal dan ikan hias dari luar.

Tabel Perbedaan Harga Jual Ikan Hias Lokal dan Ikan Hias Luar

\begin{tabular}{|c|c|c|c|c|c|c|}
\hline Jenis Ikan & $\begin{array}{l}\text { Gale-Gale } \\
\text { Olshop }\end{array}$ & $\begin{array}{l}\text { Kopet } \\
\text { Aquatic }\end{array}$ & King & $\begin{array}{l}\text { Acun } \\
\text { Aquarium }\end{array}$ & $\begin{array}{l}\text { Nuansa } \\
\text { Akuarium }\end{array}$ & $\begin{array}{l}\text { Karisma } \\
\text { Aquarium }\end{array}$ \\
\hline Ikan Lokal & $\begin{array}{l}\text { Rp 3.000; - } \\
\text { Rp } \\
\text { 200.000; }\end{array}$ & $\begin{array}{l}\text { Rp 3.000; - } \\
\text { Rp } \\
\text { 200.000; }\end{array}$ & $\begin{array}{l}\text { Rp 3.000; - } \\
\text { Rp } \\
\text { 200.000; }\end{array}$ & - & - & - \\
\hline $\begin{array}{l}\text { Ikan Hias } \\
\text { Non Lokal }\end{array}$ & - & - & - & $\begin{array}{l}\text { Rp 2.000; - } \\
\operatorname{Rp} \\
\text { 3.000.000; }\end{array}$ & $\begin{array}{l}\text { Rp 2.000; - } \\
\operatorname{Rp} \\
\text { 3.000.000; }\end{array}$ & $\begin{array}{l}\text { Rp 2.000; - } \\
\operatorname{Rp} \\
\text { 3.000.000; }\end{array}$ \\
\hline
\end{tabular}

Sumber : Toko Ikan Hias di Wilayah Kota Pangkalpinang 2021

c. Place ( Lokasi ) 
Tempat suatu usaha sangatlah penting untuk selalu dipertimbangkan, karena sebagus apapun usaha jika ditempatkan di lokasi atau tempat yang kurang atau tidak bagus maka usaha itu tidak akan berjalan dengan mulus. Lokasi yang strategis dan adanya sarana dan prasarana pendukung dalam suatu usaha sangatlah membantu dan menjadi penunjang bagi usaha tersebut. Oleh karena itu dalam memilih lokasi haruslah lebih diutamakan agar usaha yang dijalankan juga tidak memperoleh kerugian yang banyak.

Pada 3 toko ikan hias lokal yang menjadi sampel penelitian memiliki keunggulan pada lokasinya masing-masing, hal tersebut dapat dilihat pada tabel berikut :

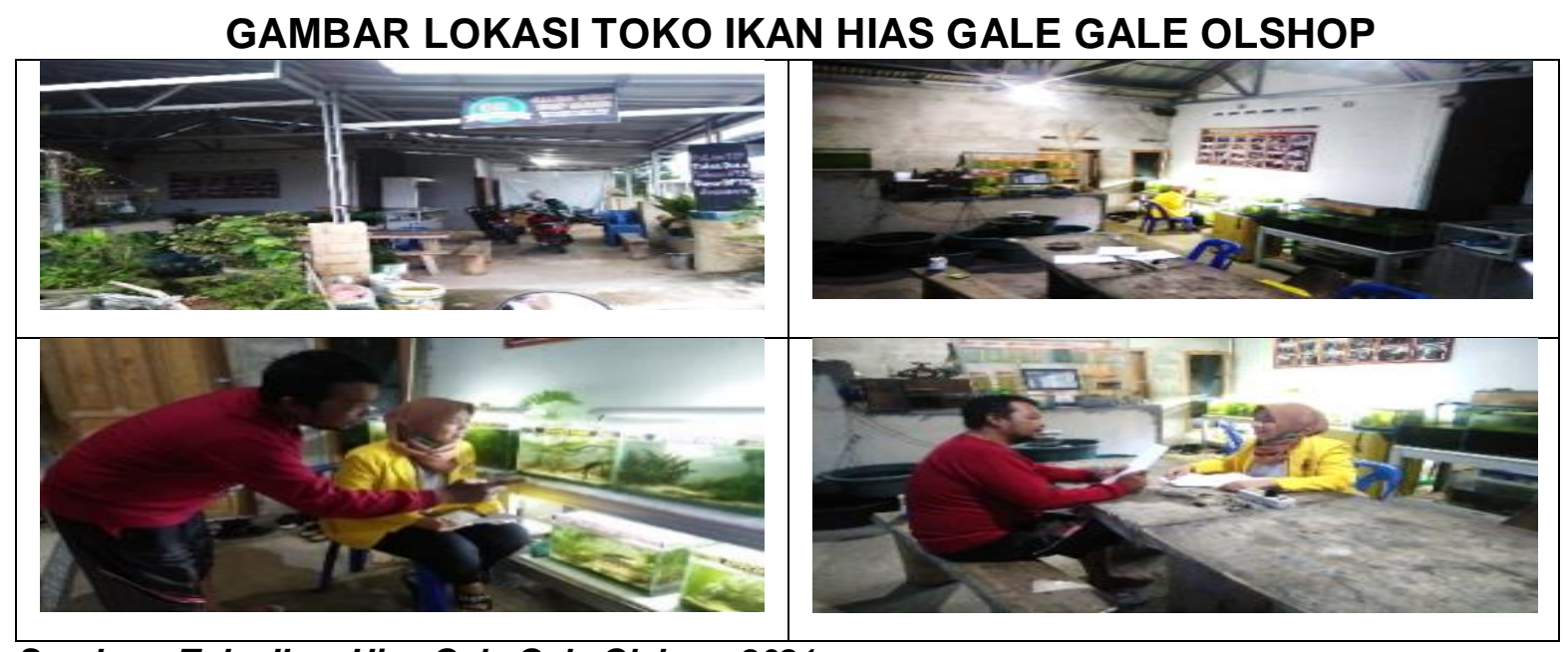

Sumber : Toko Ikan Hias Gale Gale Olshop, 2021

\section{GAMBAR LOKASI TOKO IKAN HIAS KOPET AQUATIC}

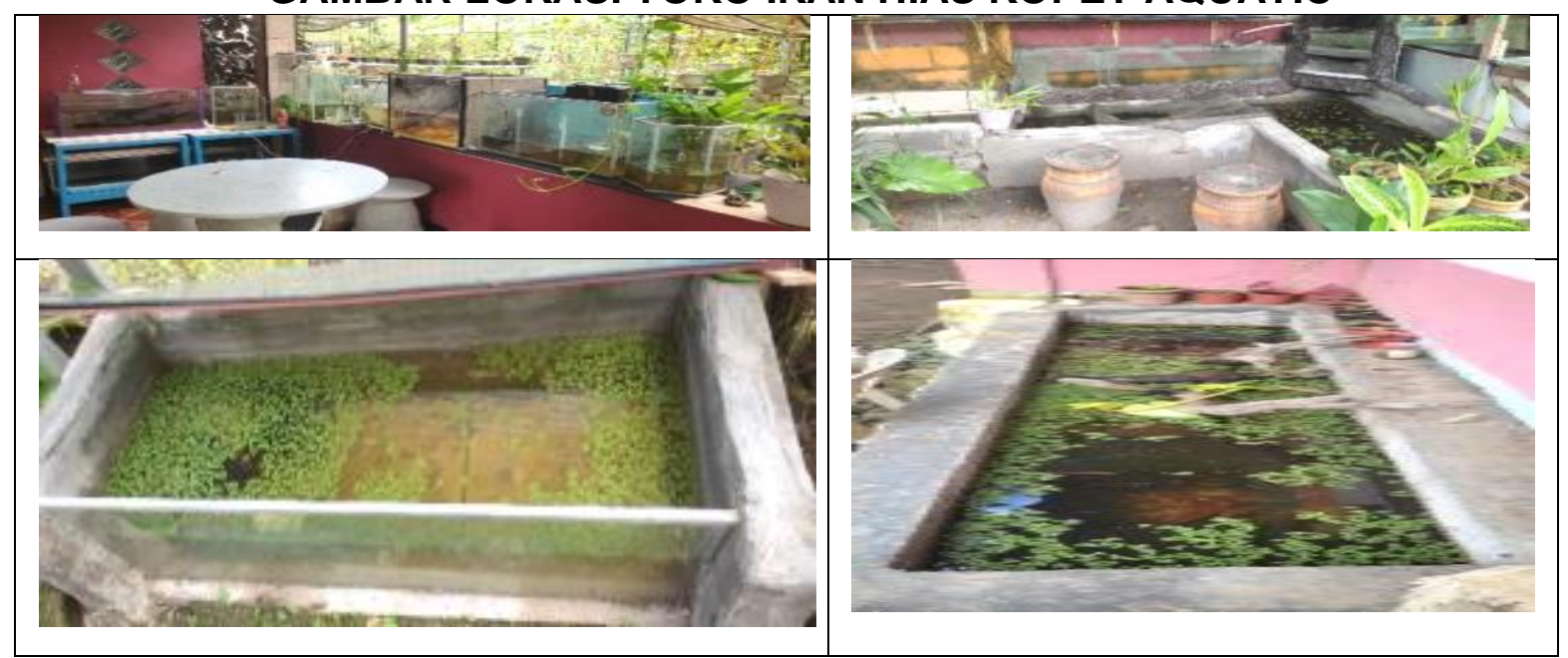

Sumber : Toko Ikan Hias Kopet Aquatic 2021 


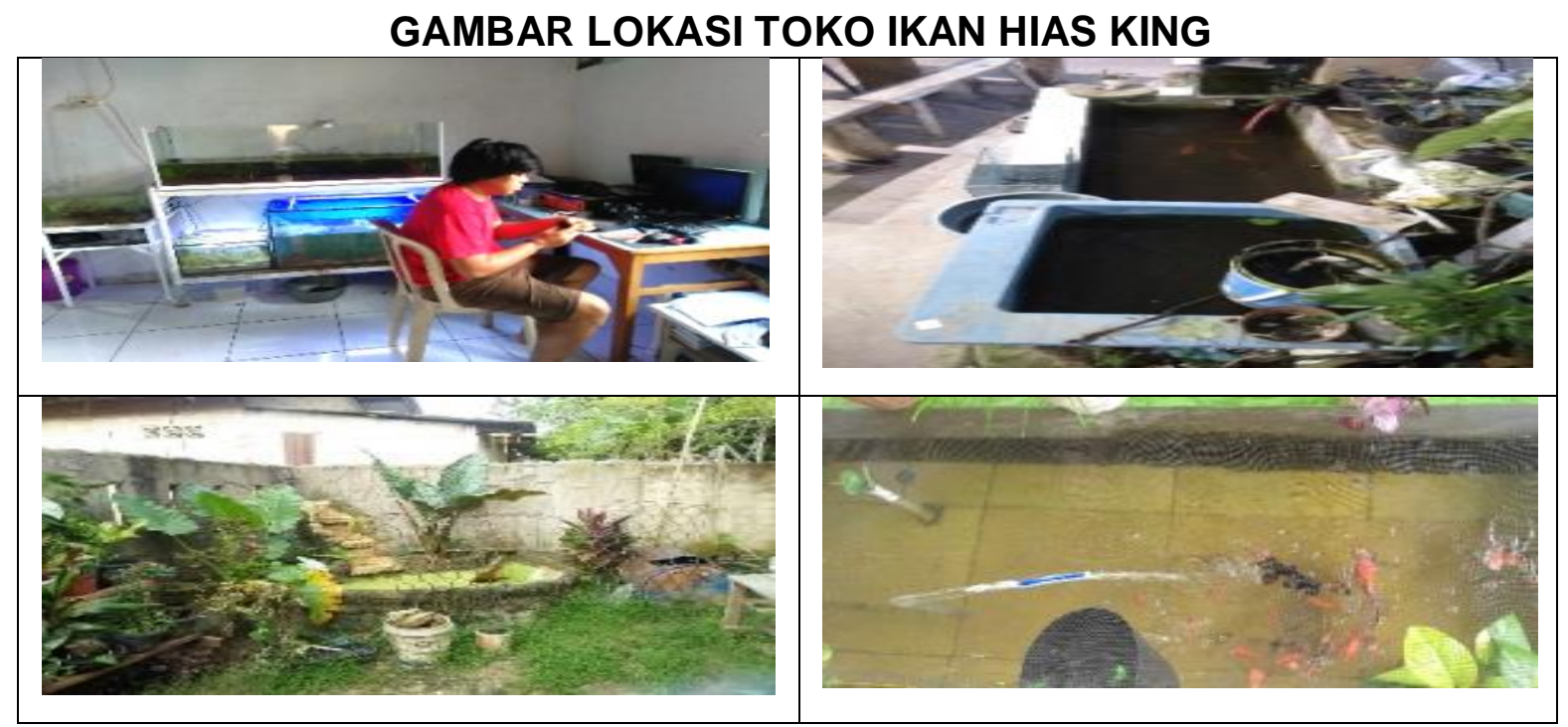

\section{Sumber : Toko Ikan Hias King 2021}

\section{d. Promotion ( Promosi )}

Terlepas dari produk, harga dan lokasi yang ditawarkan dari suatu usaha, hal yang tidak kalah pentingnya juga adalah promosi dalam memasarkan usaha itu sendiri. Promosi dalam bentuk iklan, baik iklan pada media sosial atau media tertulis, atau bentuk promo dan lainnya.

TABEL MEDIA PROMOSI PADA 3 TOKO IKAN HIAS LOKAL

\begin{tabular}{|c|c|}
\hline $\begin{array}{l}\text { Gale } \quad \text { Gale } \\
\text { Olshop }\end{array}$ & $\begin{array}{l}\text { Perumahan Lega Vista IV Blok I No } 8 \\
\text { Jln Fatmawati kampak. Gabek. Pangkalpinang } \\
\text { : Gale Gale OIShop } \\
\text { @0) :Gale_Gale_OIShope } \\
\text { (.): } 085267769989\end{array}$ \\
\hline Kopet Aquatic & $\begin{array}{l}\text { Jln Air Mawar, Gg Junai Air Mawar Bukit Intan. Pangkalpinang } \\
\text { f : Kopet Aquatic } \\
\text { (0) : Kopet_Aquatic } \\
\text { : } 082282427397\end{array}$ \\
\hline King & $\begin{array}{l}\text { Air Kepala Tujuh, Gerunggang. Pangkalpinang } \\
\text { : King Fishes Of Bangka } \\
\text { (1) :King ( fishesofbangka) } \\
\text { : } 087795357171\end{array}$ \\
\hline
\end{tabular}

Sumber : Toko Ikan Hias Lokal di Wilayah Kota Pangkalpinang 2021

\section{Pendapatan}

Pendapatan adalah hasil yang didapat berupa uang dalam suatu usaha sebagai bentuk hasil penjualan produk yang dihasilkan. Pendapatan yang diharapkan dalam suatu usaha pastilah ingin besar dan menguntungkan, namun adakalanya suatu usaha menghasilkan pendapatan lebih kecil dibandingkan pengeluaran dan juga sebaliknya. Pendapatan yang akan dihasilkan suatu usaha atau bisnis juga 
tergantung dari produk dan harga yang ditawarkan dan cara mempromosikan produk tersebut. Sama halnya dengan usaha ikan hias lokal, pada 3 toko ikan hias lokal yang menjadi sampel penelitian, disampaikan peningkatan omset pertahun selama usaha berjalan.

GRAFIK PENINGKATAN PERMINTAAN PASAR IKAN HIAS LOKAL PADA 3 TOKO IKAN

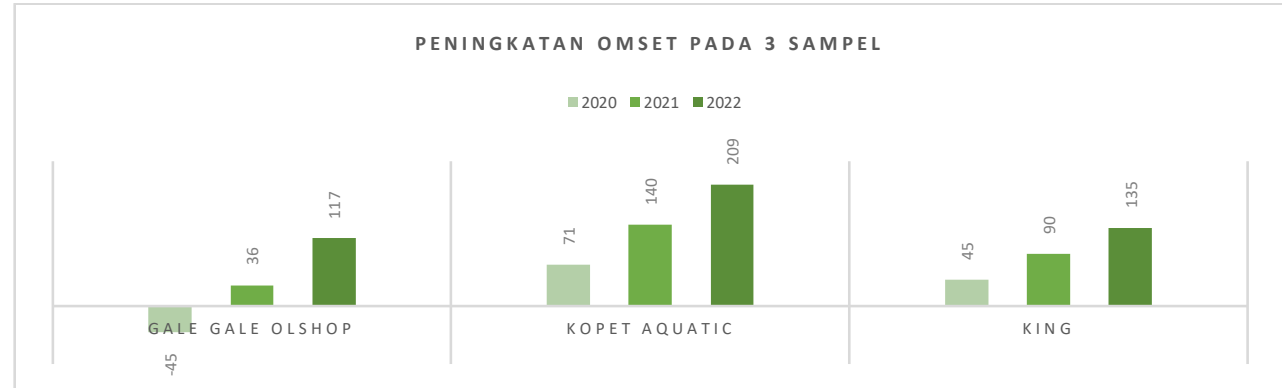

Sumber : Dari Toko Ikan Hias Lokal di Wilayah Kota Pangkalpinang 2021

\section{Hasil Analisis Aspek Pasar dan Pemasaran}

Analisis aspek pasar dan pemasaran sangat penting dilakukan karena dalam bisnis apapun harus melihat aspek pasar dan pemasarannya, agar usaha yang dijalankan mampu meminimalisir resiko yang akan terjadi, memiliki peluang yang menguntungkan dan mampu menghadapi persaingan yang bersih pada bidang usaha yang sama. Oleh karena itu analisis aspek pasar dan peasaran wajib dilakukan.

\section{Analisis Aspek Teknis}

Aspek teknis atau operasi biasa dikenal juga sebagai aspek produksi. Dalam aspek teknis memerlukan beberapa hal yang harus diperhatikan agar usaha yang dijalankan sudah sesuai dan bisa berjalan dengan teratur sebagaimana yang diinginkan.sebuah usaha yang tidak melihat aspek teknisnya maka usaha itu akan sulit dijalankan dan berkembang karena sekecil apapun sebuah usaha haruslah memiliki pedoman dan harus memenuhi kriteria usaha. Beberapa hal yang harus diperhatikan dalam aspek teknis antara lain sebagai berikut :

1. Pemilihan Lokasi yang Strategis

Pemilihan lokasi yang strategis sangat membantu dan mendukung berjalannya usaha ikan hias lokal khas Bangka belitung ini, yang mana usaha ini juga harus memperhatikan lingkungan internal dan eksternalnya, agar operasional usaha tetap berjalan dengan baik.

2. Skala Produk dan Produksi yang Optimal

Produk yang memiliki kualitas yang baik adalah produk yang dihasilkan dan dipelihara dengan baik pula, ikan hias yang berhasil dilakukan pemijahan akan dirawat dengan baik,diberikan vitamin dan pakan yang cukup serta cocok untuk pertumbuhan warna dan bobot ikan.

3. Teknologi yang digunakan

Dalam proses pemijahan ikan-ikan hias lokal menggunakan teknologi yang sudah modern dan mumpuni, baik dari proses awal pemijahan sampai perawatan benih-benih ikan yang memang harus dijaga kestabilan mineral air, suhu, pakan dan tempatnya. 


\section{Display Bangunan}

Display bangunan dalam setiap usaha ikan hias hampir sama dan tidak memiliki perbedaan, akan tetapi pada usaha ikan hias lokal ini memiliki display pajangan akuarium yang berbeda dari toko ikan hias lainnya, karena pada toko-toko ikan hias lokal ini memiliki display pajangan yang lebih unik dan menarik, seperti pada gambar berikut.

\section{GAMBAR DISPLAY/PAJANGAN AKUARIUM PADA TOKO IKAN HIAS LOKAL}

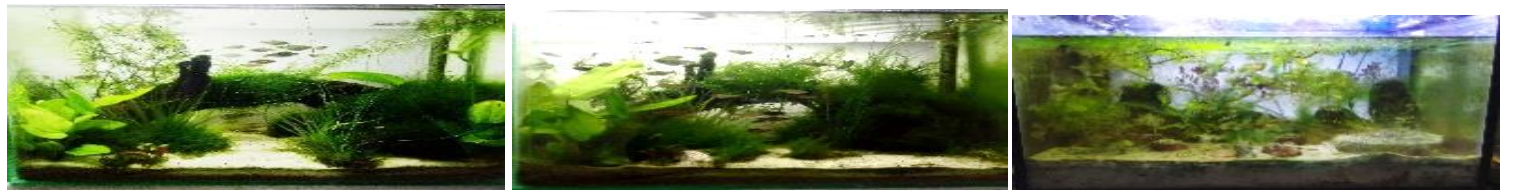

Sumber: Toko Ikan Hias Lokal di Wilayah Kota Pangkalpinang 2021

\section{Sarana dan Prasarana}

Sarana dan prasarana dalam usaha ikan hias ini sudah memadai dan modern, dalam proses penyaluran bibit ataupun ikan-ikan hias yang didapat dari pemasok sudah menggunakan sarana yang cukup baik. Oleh karena itu, usaha ikan hias lokal ini sudah berjalan dan beroperasional dengan baik.

\section{Hasil Analisis Aspek Teknis}

Analisis aspek teknis juga sangat penting untuk dilakukan untuk memastikan usaha yang akan dijalan atau sudah berjalan bisa beradaptasi dan memiliki inovasiinovasi terbaru dalam menghadapi tantangan, baik tantangan dari usaha pesaing ataupun tantangan dari internal usaha itu sendiri.

\section{Analisis Kelayakan Finansial}

Analisis kelayakan usaha tidak lepas dari analisa tentang keuangan atau finansialnnya. Sebuah usaha atau bisnis pastinya ingin mendapatkan keuntungan yang sebesar-besarnya dan mengeluarkan biaya operasional sekecil-kecilnya. Namun tidak ada usaha atau bisnis yang mengeluarkan biaya operasional kecil akan mendapatkan keuntungan yang besar, malah sebaliknya dalam sebuah usaha jika ingin mendapatkan keuntungan yang besar sebagai pelaku usaha jangan takut mengeluarkan modal yang besar, tapi hal itu juga harus memperhatikan peluang dan tata cara dalam menjalani usaha itu sendiri, jika kita mampu mengeluarkan modal yang besar dan strategi bisnis yang baik serta inovasi-inovasi yang kreatif dijalankan dalam usaha tersebut, maka tidak mustahil akan menghasilkan keuntungan yang besar.

Analisis finansial adalah suatu analisis yang melihat apakah suatu proyek menguntungkan selama umur bisnis (Husnan \& Muhammad, 2000).

Perhitungan dalam aspek kelayakan finansial atau keuangan dilihat dari beberapa analisa atau perhitungan, diantaranya adalah :

1. Kebutuhan Dana Investasi

a. Biaya Investasi

Dalam menjalankan usaha ikan hias lokal khas bangka Belitung ini diperlukan beberapa biaya untuk perlengkapan dan peralatan. Pada usaha ikan hias lokal ini biaya yang digunakan menggunakan biaya atau modal pribadi dengan modal yang masih kecil atau sedikit. 
TABEL BIAYA INVESTASI PADA 3 TOKO IKAN HIAS LOKAL

\begin{tabular}{|c|c|r|r|}
\hline No & Nama Toko Ikan Hias & Biaya Investasi & Total Biaya Investasi \\
\hline 1 & Gale Gale Olshop & $\operatorname{Rp~74.832.000;~}$ & $\operatorname{Rp~75.000.000;~}$ \\
\hline 2 & Kopet Aquatic & $\operatorname{Rp~58.150.000;~}$ & $\operatorname{Rp~60.000.000;~}$ \\
\hline 3 & King & $R p ~ 44.920 .000 ;$ & $\operatorname{Rp~45.000.000;~}$ \\
\hline 4 & Toko Referensi & $\operatorname{Rp~23.790.000;~}$ & $\operatorname{Rp~25.000.000;~}$ \\
\hline
\end{tabular}

Sumber : Toko Ikan Hias Lokal di Wilayah Kota Pangkalpinang 2021

b. Biaya Operasional

TABEL BIAYA OPERASIONAL PADA 3 TOKO IKAN HIAS LOKAL

\begin{tabular}{|c|c|c|c|}
\hline No & Nama Toko Ikan Hias & $\begin{array}{c}\text { Biaya Operasional } \\
\text { 1 Bulan }\end{array}$ & $\begin{array}{c}\text { Total Biaya } \\
\text { Operasional }\end{array}$ \\
\hline 1 & Gale Gale Olshop & $\operatorname{Rp~10.000.000;~}$ & Rp 120.000.000; \\
\hline 2 & Kopet Aquatic & $\operatorname{Rp~8.300.000;~}$ & Rp 99.600.000; \\
\hline 3 & King & $R p 8.000 .000 ;$ & $R p 96.000 .000 ;$ \\
\hline 4 & Toko Referensi & $R p 6.550 .000 ;$ & $R p ~ 78.600 .000 ;$ \\
\hline
\end{tabular}

Sumber : Toko Ikan Hias Lokal di Wilayah Kota Pangkalpinang 2021

c. Pendapatan

TABEL PENDAPATAN PADA TOKO IKAN HIAS LOKAL

\begin{tabular}{|c|c|r|c|}
\hline No & Nama Toko Ikan Hias & $\begin{array}{c}\text { Pendapatan 1 } \\
\text { Bulan }\end{array}$ & $\begin{array}{c}\text { Total Pendapatan } \\
\text { 1 Tahun }\end{array}$ \\
\hline 1 & Gale Gale Olshop & $\operatorname{Rp~17.175.000;~}$ & Rp 206.100.000; \\
\hline 2 & Kopet Aquatic & $\operatorname{Rp~14.480.000;~}$ & Rp 176.760.000; \\
\hline 3 & King & $R p ~ 12.170 .000 ;$ & $R p ~ 146.040 .000 ;$ \\
\hline 4 & Toko Referensi & $\operatorname{Rp~9.105.000;~}$ & Rp 109.260.000; \\
\hline
\end{tabular}

Sumber : Toko Ikan Hias Lokal di Wilayah Kota Pangkalpinang 2021

\section{Analisis Kelayakan Bisnis}

Suatu usaha dikatakan baik jika menghasilkan keuntungan yang layak dan mampu memenuhi kewajiban keuangannya. Pada aspek kelayakan bisnis berkaitan dengan metode perhitungan dalam menilai sebuah usaha apakah mendapatkan keuntungan atau malah rugi, perhitungan dalam aspek kelayakan bisnis diantaranya adalah :

\section{Estimasi Laba Rugi}

Berikut ini merupakan estimasi laporan laba rugi pada toko Gale Gale Olshop, Kopet Aquatic, King dan toko referensi usaha ikan hias lokal khas Bangka Belitung di wilayah kota Pangkalpinang dengan penyusutan Rp. 5.000.000; (Lima Juta Rupiah) pertahun.

TABEL ESTIMASI LABA RUGI PADA TOKO GALE GALE OLSHOP

\begin{tabular}{|c|r|}
\hline Keterangan & Nilai \\
\hline Pendapatan & Rp 206.100.000; \\
\hline Biaya Penyusutan & $\operatorname{Rp~5.000.000;~}$ \\
\hline Biaya Operasional & $\operatorname{Rp~} 20.000 .000 ;$ \\
\hline Laba Sebelum Pajak & $\operatorname{Rp~8.1100.000;}$ \\
\hline Pajak 10\% & $\operatorname{Rp~72.990.000;}$ \\
\hline Laba Setelah pajak &
\end{tabular}

Sumber : Toko Gale Gale Olshop Diolah Oleh Penulis, 2021 
Aliran kas masuk = laba bersih + penyusutan

$=\operatorname{Rp~72.990.000;+Rp~5.000.000;~}$

$=\operatorname{Rp} 77.990 .000$;

TABEL ESTIMASI LABA RUGI PADA TOKO KOPET AQUATIC

\begin{tabular}{|c|r|}
\hline Keterangan & Nilai \\
\hline Pendapatan & Rp 173.760.000; \\
\hline Biaya Penyusutan & $R p ~ 5.000 .000 ;$ \\
\hline Biaya Operasional & $\operatorname{Rp~99.600.000;~}$ \\
\hline \hline Laba Sebelum Pajak $69.160 .000 ;$ \\
\hline Pajak 10\% & $R p ~ 6.916 .000 ;$ \\
\hline Laba Setelah pajak & $\operatorname{Rp~62.244.000;}$ \\
\hline
\end{tabular}

Sumber : Toko Kopet Aquatik Diolah Oleh Penulis, 2021

Aliran kas masuk = laba bersih + penyusutan

$=\operatorname{Rp~62.244.000;~+~Rp~5.000.000;~}$

= Rp 67.244.000;

TABEL ESTIMASI LABA RUGI PADA TOKO KING

\begin{tabular}{|c|r|}
\hline Keterangan & Nilai \\
\hline Pendapatan & Rp 146.040.000; \\
\hline Biaya Penyusutan & Rp 5.000.000; \\
\hline Biaya Operasional & Rp.000.000; \\
\hline \hline Laba Sebelum Pajak & Rp 4.040.000; \\
\hline Pajak 10\% & Rp 40.536.000; \\
\hline Laba Setelah pajak &
\end{tabular}

Sumber : Toko King Diolah Oleh Penulis, 2021

Aliran kas masuk = laba bersih + penyusutan

$=\operatorname{Rp~40.536.000;~+~Rp~5.000.000;~}$

$=\operatorname{Rp~45.536.000;}$

TABEL ESTIMASI LABA RUGI PADA TOKO REFERENSI USAHA

\begin{tabular}{|c|r|}
\hline Keterangan & Nilai \\
\hline Pendapatan & Rp 109.260.000; \\
\hline Biaya Penyusutan & Rp 5.000.000; \\
\hline Biaya Operasional & Rp 78.600.000; \\
\hline Laba Sebelum Pajak & Rp 25.660.000; \\
\hline Pajak 10\% & Rp 2.556.000; \\
\hline Laba Setelah pajak & Rp 23.094.000; \\
\hline
\end{tabular}

Sumber : Toko Referensi Diolah Oleh Penulis, 2021

Aliran kas masuk = laba bersih + penyusutan

$=\operatorname{Rp} 23.094 .000 ;+\operatorname{Rp~5.000.000;~}$

= Rp 28.094.000; 


\section{Estimasi Cash Flow}

Estimasi cash flow pada 3 toko ikan hias lokal sebagai sampel penelitian dan toko referensi usaha ikan hias lokal khas Bangka Belitung di wilayah kota Pangkalpinang dari tahun 2020 sampai dengan tahun 2022 dapat dilihat pada tabeltabel berikut.

TABEL ESTIMASI CASH FLOW PADA TOKO IKAN HIAS GALE GALE OLSHOP

\begin{tabular}{|l|r|r|r|}
\hline \multirow{2}{*}{ Komponen } & \multicolumn{3}{c|}{ Tahun / Periode } \\
\cline { 2 - 4 } & \multicolumn{1}{|c|}{$\mathbf{2 0 2 0}$} & \multicolumn{1}{c|}{$\mathbf{2 0 2 1}$} & \multicolumn{1}{c|}{2022} \\
\hline KAS MASUK & & & \\
\hline Investasi Awal & 75.000 .000 & & 206.100 .000 \\
\hline Pendapatan & 206.100 .000 & 206.100 .000 & 206.100 .000 \\
\hline Total Kas Masuk & 206.100 .000 & 206.100 .000 & \\
\hline KAS KELUAR & & & $\mathbf{1 2 0 . 0 0 0 . 0 0 0}$ \\
\hline Pembelian Aktiva Tetap & $\mathbf{1 2 0 . 0 0 0 . 0 0 0}$ & $\mathbf{1 2 0 . 0 0 0 . 0 0 0}$ & 3.000 .000 \\
\hline Penyusutan Gedung & 3.000 .000 & 3.000 .000 & 2.000 .000 \\
\hline Penyusutan Peralatan & 2.000 .000 & 2.000 .000 & 88.800 .000 \\
\hline Gaji dan Upah & 88.800 .000 & 88.800 .000 & 18.000 .000 \\
\hline Listrik dan Air & 18.000 .000 & 18.000 .000 & 3.600 .000 \\
\hline Promosi/lklan & 3.600 .000 & 3.600 .000 & 9.600 .000 \\
\hline Biaya ATK & 9.600 .000 & 9.600 .000 & $\mathbf{1 2 5 . 0 0 0 . 0 0 0}$ \\
\hline Total Kas Keluar & $\mathbf{1 2 5 . 0 0 0 . 0 0 0}$ & $\mathbf{1 2 5 . 0 0 0 . 0 0 0}$ & $\mathbf{8 1 . 1 0 0 . 0 0 0}$ \\
\hline Surplus / Defisit & $\mathbf{8 1 . 1 0 0 . 0 0 0}$ & $\mathbf{8 1 . 1 0 0 . 0 0 0}$ & $\mathbf{8 1 . 0 0 0}$ \\
\hline Saldo Kas & $\mathbf{- 4 5 . 0 0 0 . 0 0 0}$ & $\mathbf{3 6 . 1 0 0 . 0 0 0}$ & $\mathbf{1 1 7 . 2 0 0 . 0 0 0}$ \\
\hline
\end{tabular}

Sumber : Toko Ikan Gale Gale Olshop Diolah Oleh Penulis, 2021

TABEL ESTIMASI CASH FLOW PADA TOKO IKAN HIAS KOPET AQUATIC

\begin{tabular}{|l|r|r|r|}
\hline \multirow{2}{*}{ Komponen } & \multicolumn{3}{|c|}{ Tahun / Periode } \\
\cline { 2 - 4 } & $\mathbf{2 0 1 9}$ & \multicolumn{1}{c|}{$\mathbf{2 0 2 0}$} & \multicolumn{1}{c|}{2021} \\
\hline KAS MASUK & & & \\
\hline Investasi Awal & 60.000 .000 & & 173.760 .000 \\
\hline Pendapatan & 173.760 .000 & 173.760 .000 & \\
\hline Total Kas Masuk & 173.760 .000 & 173.760 .000 & 173.760 .000 \\
\hline KAS KELUAR & & & 58.150 .000 \\
\hline Pembelian Aktiva Tetap & $\mathbf{5 8 . 1 5 0 . 0 0 0}$ & $\mathbf{5 8 . 1 5 0 . 0 0 0}$ & 3.000 .000 \\
\hline Penyusutan Gedung & 3.000 .000 & 3.000 .000 & 2.000 .000 \\
\hline Penyusutan Peralatan & 2.000 .000 & 2.000 .000 & 79.200 .000 \\
\hline Gaji dan Upah & 79.200 .000 & 79.200 .000 & 12.000 .000 \\
\hline Listrik dan Air & 12.000 .000 & 12.000 .000 & 2.400 .000 \\
\hline Promosi/lklan & 2.400 .000 & 2.400 .000 & 6.000 .000 \\
\hline Biaya ATK & 6.000 .000 & 6.000 .000 & $\mathbf{1 0 4 . 6 0 0 . 0 0 0}$ \\
\hline Total Kas Keluar & $\mathbf{1 0 4 . 6 0 0 . 0 0 0}$ & $\mathbf{1 0 4 . 6 0 0 . 0 0 0}$ & $\mathbf{6 9 . 1 6 0 . 0 0 0}$ \\
\hline Surplus / Defisit & $\mathbf{6 9 . 1 6 0 . 0 0 0}$ & $\mathbf{6 9 . 1 6 0 . 0 0 0}$ & $\mathbf{2 0 9 . 3 3 0 . 0 0 0}$ \\
\hline Saldo Kas & $\mathbf{7 1 . 0 1 0 . 0 0 0}$ & $\mathbf{1 4 0 . 1 7 0 . 0 0 0}$ & \\
\hline
\end{tabular}

Sumber : Toko Kopet Aquatik Diolah Oleh Penulis, 2021 
TABEL ESTIMASI CASH FLOW PADA TOKO IKAN KING

\begin{tabular}{|l|r|r|r|}
\hline \multirow{2}{*}{ Komponen } & \multicolumn{3}{|c|}{ Tahun / Periode } \\
\cline { 2 - 4 } & $\mathbf{2 0 1 9}$ & $\mathbf{2 0 2 0}$ & \multicolumn{1}{c|}{$\mathbf{2 0 2 1}$} \\
\hline KAS MASUK & & & \\
\hline Investasi Awal & 50.000 .000 & & 146.040 .000 \\
\hline Pendapatan & 146.040 .000 & 146.040 .000 & \\
\hline Total Kas Masuk & 146.040 .000 & 146.040 .000 & 146.040 .000 \\
\hline & & & \\
\hline KAS KELUAR & & & $\mathbf{4 4 . 9 2 0 . 0 0 0}$ \\
\hline Pembelian Aktiva Tetap & $\mathbf{4 4 . 9 2 0 . 0 0 0}$ & $\mathbf{4 4 . 9 2 0 . 0 0 0}$ & 3.000 .000 \\
\hline Penyusutan Gedung & 3.000 .000 & 3.000 .000 & 2.000 .000 \\
\hline Penyusutan Peralatan & 2.000 .000 & 2.000 .000 & 76.800 .000 \\
\hline Gaji dan Upah & 76.800 .000 & 76.800 .000 & 10.800 .000 \\
\hline Listrik dan Air & 10.800 .000 & 10.800 .000 & 2.400 .000 \\
\hline Promosi/Iklan & 2.400 .000 & 2.400 .000 & 6.000 .000 \\
\hline Biaya ATK & 6.000 .000 & 6.000 .000 & $\mathbf{1 0 1 . 0 0 0 . 0 0 0}$ \\
\hline Total Kas Keluar & $\mathbf{1 0 1 . 0 0 0 . 0 0 0}$ & $\mathbf{1 0 1 . 0 0 0 . 0 0 0}$ & $\mathbf{4 5 . 0 4 0 . 0 0 0}$ \\
\hline Surplus / Defisit & $\mathbf{4 5 . 0 4 0 . 0 0 0}$ & $\mathbf{4 5 . 0 4 0 . 0 0 0}$ & $\mathbf{9 0 . 1 6 0 . 0 0 0}$ \\
\hline Saldo Kas & $\mathbf{4 5 . 1 2 0 . 0 0 0}$ & $\mathbf{1 3 5 . 2 0 0 . 0 0 0}$ \\
\hline
\end{tabular}

Sumber : Toko King Diolah Oleh Penulis, 2021

TABEL ESTIMASI CASH FLOW PADA TOKO REFERENSI USAHA

\begin{tabular}{|l|r|r|r|}
\hline \multirow{2}{*}{ Komponen } & \multicolumn{3}{|c|}{ Tahun / Periode } \\
\cline { 2 - 4 } & $\mathbf{2 0 2 0}$ & $\mathbf{2 0 2 1}$ & \multicolumn{1}{c|}{$\mathbf{2 0 2 2}$} \\
\hline KAS MASUK & & & \\
\hline Investasi Awal & 25.000 .000 & & 109.260 .000 \\
\hline Pendapatan & 109.260 .000 & 109.260 .000 & \\
\hline Total Kas Masuk & 109.260 .000 & 109.260 .000 & 109.260 .000 \\
\hline & & & \\
\hline KAS KELUAR & & & $\mathbf{2 3 . 7 9 0 . 0 0 0}$ \\
\hline Pembelian Aktiva Tetap & $\mathbf{2 3 . 7 9 0 . 0 0 0}$ & $\mathbf{2 3 . 7 9 0 . 0 0 0}$ & 3.000 .000 \\
\hline Penyusutan Gedung & 3.000 .000 & 3.000 .000 & 2.000 .000 \\
\hline Penyusutan Peralatan & 2.000 .000 & 2.000 .000 & 63.600 .000 \\
\hline Gaji dan Upah & 63.600 .000 & 63.600 .000 & 9.000 .000 \\
\hline Listrik dan Air & 9.000 .000 & 9.000 .000 & 2.400 .000 \\
\hline Promosi/Iklan & 2.400 .000 & 2.400 .000 & 3.600 .000 \\
\hline Biaya ATK & 3.600 .000 & 3.600 .000 & $\mathbf{8 3 . 6 0 0 . 0 0 0}$ \\
\hline Total Kas Keluar & $\mathbf{8 3 . 6 0 0 . 0 0 0}$ & $\mathbf{8 3 . 6 0 0 . 0 0 0}$ & $\mathbf{2 5 . 6 6 0 . 0 0 0}$ \\
\hline Surplus / Defisit & $\mathbf{2 5 . 6 6 0 . 0 0 0}$ & $\mathbf{2 5 . 6 6 0 . 0 0 0}$ & $\mathbf{7 8 . 1 9 0 . 0 0 0}$ \\
\hline Saldo Kas & $\mathbf{2 6 . 8 7 0 . 0 0 0}$ & $\mathbf{5 2 . 5 3 0 . 0 0 0}$ & \\
\hline
\end{tabular}

Sumber : Toko Referensi Diolah Oleh Penulis, 2021 
Tabel Cash Flow Dari 3 Toko Sampel Dan 1 Toko Referensi

TABEL CASH FLOW PADA TOKO GALE GALE OLSHOP

\begin{tabular}{|c|c|c|r|r|r|r|}
\hline \multirow{2}{*}{ No } & \multirow{2}{*}{ Tahun } & EAT & \multirow{2}{*}{ PENYUSUTAN } & KAS BERSIH & $\begin{array}{c}\text { DISCOUNT } \\
\text { FACTOR }\end{array}$ & \multirow{2}{*}{$\begin{array}{c}\text { PV KAS } \\
\text { BERSIH }\end{array}$} \\
\cline { 5 - 6 } & & & & (PROCEED) & (DF 2096) & \\
\hline 1 & 2020 & Rp72.990.000 & Rp5 5000.000 & Rp77.880.000 & 0.833 & Rp64.874.040 \\
\hline 2 & 2021 & Rp72.990.000 & Rp5.000.000 & Rp77.880.000 & 0,694 & Rp54.048.720 \\
\hline 3 & 2022 & Rp72.990.000 & Rp5.000.000 & Rp77.880.000 & 0.579 & Rp45.092.520 \\
\hline \multicolumn{7}{|c|}{ Jumlah PV Kas Bersih } \\
\hline
\end{tabular}

Sumber dari Toko Ikan Hias Lokal Gale Gale Olshop

TABEL CASH FLOW PADA TOKO KOPET AQUATIC

\begin{tabular}{|c|c|r|r|r|r|c|}
\hline \multirow{2}{*}{ No } & \multirow{2}{*}{ Tahun } & EAT & \multirow{2}{*}{ PENYUSUTAN } & KAS BERSIH & $\begin{array}{c}\text { DISCOUNT } \\
\text { FACTOR }\end{array}$ & \multirow{2}{*}{$\begin{array}{c}\text { PV KAS } \\
\text { BERSIH }\end{array}$} \\
\cline { 5 - 6 } & & & & (PROCEED) & (DF 20\%) & \\
\hline 1 & 2019 & Rp62.244.000 & Rp5.000.000 & Rp67.244.000 & 0,833 & Rp56.014.252 \\
\hline 2 & 2020 & Rp62.244.000 & Rp5.000.000 & Rp67.244.000 & 0,694 & Rp46.667.336 \\
\hline 3 & 2021 & Rp62.244.000 & Rp5.000.000 & Rp67.244.000 & 0,579 & Rp38.934.276 \\
\hline \multicolumn{5}{|c}{ Jumlah PV Kas Bersih } & Rp141.615.864 \\
\hline
\end{tabular}

Sumber dari Toko Ikan Hias Kopet Aquatic

TABEL CASH FLOW PADA TOKO KING

\begin{tabular}{|c|c|c|r|r|r|r|}
\hline \multirow{2}{*}{ No } & \multirow{2}{*}{ Tahun } & \multirow{2}{*}{ EAT } & \multirow{2}{*}{ PENYUSUTAN } & $\begin{array}{c}\text { KAS } \\
\text { BERSIH }\end{array}$ & $\begin{array}{c}\text { DISCOUNT } \\
\text { FACTOR }\end{array}$ & \multirow{2}{*}{$\begin{array}{c}\text { PV KAS } \\
\text { BERSIH }\end{array}$} \\
\cline { 5 - 6 } & & & & (PROCEED) & (DF 209) $)$ & \\
\hline 1 & 2019 & Rp40.536.000 & Rp5.000.000 & Rp45.536.000 & 0,833 & Rp37.931.488 \\
\hline 2 & 2020 & Rp40.536.000 & Rp5.000.000 & Rp45.536.000 & 0,694 & Rp31.601.984 \\
\hline 3 & 2021 & Rp40.536.000 & Rp5.000.000 & Rp45.536.000 & 0,579 & Rp26.365.344 \\
\hline \multicolumn{7}{|c|}{ Jumlah PV Kas Bersih } \\
\hline
\end{tabular}

Sumber dari Toko Ikan Hias Lokal King

TABEL CASH FLOW PADA TOKO REFERENSI USAHA

\begin{tabular}{|c|c|c|c|c|c|c|}
\hline \multirow[t]{2}{*}{ No } & \multirow[t]{2}{*}{ Tahun } & \multirow[t]{2}{*}{ EAT } & \multirow[t]{2}{*}{ PENYUSUTAN } & KAS BERSIH & $\begin{array}{c}\text { DISCOUNT } \\
\text { FACTOR } \\
\end{array}$ & \multirow{2}{*}{$\begin{array}{l}\text { PV KAS } \\
\text { BERSIH }\end{array}$} \\
\hline & & & & (PROCEED) & (DF 209\%) & \\
\hline 1 & 2020 & $\mathrm{Rp} 23.094 .000$ & $\operatorname{Rp} 5.000 .000$ & Rp 28.094 .000 & 0,833 & $\operatorname{Rp} 23.402 .302$ \\
\hline 2 & 2021 & Rp 23.094.000 & $\operatorname{Rp} 5.000 .000$ & $\operatorname{Rp} 28.094 .000$ & 0,694 & Rp 19.497.236 \\
\hline 3 & 2022 & Rp 23.094.000 & $\operatorname{Rp} 5.000 .000$ & Rp 28.094 .000 & 0,579 & $\mathrm{Rp} 16.266 .426$ \\
\hline \multicolumn{6}{|c|}{ Jumlah PV Kas Bersih } & Rp 59.165.964 \\
\hline
\end{tabular}

Sumber dari hasil olahan data penulis pada toko referensi ikan hias lokal 2021 


\section{Net Present Value}

\section{TABEL NPV PADA TOKO GALE GALE OLSHOP}

\begin{tabular}{|c|c|r|}
\hline \multirow{2}{*}{ NPV $=$} & $\begin{array}{c}\text { PV Kas Bersih - Nilai } \\
\text { Investasi }\end{array}$ & $\mathrm{Rp} 164.015 .280$ \\
\cline { 3 - 3 } & & $\mathrm{Rp} 75.000 .000$ \\
\cline { 3 - 3 } & & $\mathrm{Rp} 89.015 .280$ \\
\hline
\end{tabular}

Sumber dari Toko Ikan Hias Lokal Gale Gale Olshop

\section{TABEL NPV PADA TOKO KOPET AQUATIC}

\begin{tabular}{|c|c|r|}
\hline \multirow{2}{*}{$\mathrm{NPV}=$} & \multirow{2}{*}{$\begin{array}{c}\text { PV Kas Bersih - Nilai } \\
\text { Investasi }\end{array}$} & $\mathrm{Rp} 141.615 .864$ \\
\cline { 3 - 3 } & & $\mathrm{Rp}$ 81.615.000.000 \\
& &
\end{tabular}

Sumber dari Toko Ikan Hias Lokal Kopet Aquatic

\section{TABEL NPV PADA TOKO KING}

\begin{tabular}{|c|c|r|}
\hline \multirow{2}{*}{ NPV $=$} & PV Kas Bersih - Nilai & $R p 95.898 .816$ \\
& Investasi & $R p 45.000 .000$ \\
& & $R p 50.898 .816$ \\
\hline
\end{tabular}

Sumber dari Toko Ikan Hias Lokal King

\section{TABEL NPV PADA TOKO REFERENSI USAHA}

\begin{tabular}{|c|c|c|}
\hline \multirow{3}{*}{$\mathrm{NPV}=$} & \multirow{3}{*}{$\begin{array}{c}\text { PV Kas Bersih - Nilai } \\
\text { Investasi }\end{array}$} & Rp 59.165.964 \\
\hline & & $\operatorname{Rp} 25.000 .000$ \\
\hline & & Rp 34.165.964 \\
\hline
\end{tabular}

Sumber dari hasil olahan data penulis pada toko referensi ikan hias lokal 2021

\section{Average Rate Of Return}

\section{TABEL ARR PADA TOKO GALE GALE OLSHOP}

\begin{tabular}{|c|l|r|c|}
\hline \multirow{2}{*}{$A R R=$} & Laba setelah pajak & Rp 72.990 .000 & \multirow{2}{*}{$97 \%$} \\
\cline { 2 - 3 } & Investasi awal & Rp 75.000 .000 & \\
\hline
\end{tabular}

Sumber dari Toko Ikan Hias Lokal Gale Gale Olshop

TABEL ARR PADA TOKO KOPET AQUATIC

\begin{tabular}{|l|l|r|l|}
\hline \multirow{2}{*}{$A R R=$} & Laba setelah pajak & Rp 62.244.000 & \multirow{2}{*}{$103 \%$} \\
\cline { 2 - 3 } & Investasi awal & Rp 60.000.000 & \\
\hline
\end{tabular}

Sumber dari Toko Ikan Hias Kopet Aquatic

\section{TABEL ARR PADA TOKO KING}

\begin{tabular}{|l|l|r|c|}
\hline \multirow{2}{*}{$A R R=$} & Laba setelah pajak & Rp 40.536.000; & \multirow{2}{*}{$90 \%$} \\
\cline { 2 - 3 } & Inveatasi awal & Rp45.000.000 & \\
\hline
\end{tabular}

Sumber dari Toko Ikan Hias King 
Tabel ARR pada Toko Referensi Usaha

\begin{tabular}{|c|l|r|c|}
\hline \multirow{2}{*}{ ARR $=$} & Laba setelah pajak & Rp23.094.000 & \multirow{2}{*}{$92 \%$} \\
\cline { 2 - 3 } & Inveatasi awal & Rp25.000.000 & \\
\hline
\end{tabular}

Sumber dari hasil olaham data penulis pada toko referensi ikan hias lokal 2021

\section{Payback Periode}

TABEL PP PADA TOKO GALE GALE OLSHOP

\begin{tabular}{|c|l|l|l|}
\hline \multirow{2}{*}{$\mathrm{pP}=$} & Invedasi & Rp 750000000; & \multirow{2}{*}{0,96} \\
\cline { 2 - 3 } & Pendapetan & Rp 77.800000, & \\
\hline
\end{tabular}

Sumber dari Toko Ikan Hias Gale Gale Olshop

\section{TABEL PP PADA TOKO KOPET AQUATIC}

\begin{tabular}{|c|c|c|c|}
\hline \multirow{2}{*}{$\mathrm{pP}=$} & Invetasi & $\operatorname{Rp} 60.000000 ;$ & \multirow{2}{*}{0,89} \\
\hline & Pendapian & Rp 67.244.000: & \\
\hline
\end{tabular}

Sumber dari Tolo Ihan Hias Ropet Aquatic

Tabel PP pada Toko King

\begin{tabular}{|c|l|c|c|}
\hline \multirow{2}{*}{$\mathrm{pp}=$} & Investasi & Rp 45.000.000; & \multirow{2}{*}{0,98} \\
\cline { 2 - 3 } & Pendaptan & Rp 45.536.000; & \\
\hline
\end{tabular}

Sumber dari Toko Ikan Hias King

\section{Tabel PP pada Toko Referensi Usaha}

\begin{tabular}{|c|l|r|c|}
\hline \multirow{2}{*}{$\mathrm{pp}=$} & Invetasi & Rp 25000.00; & \multirow{2}{*}{0,88} \\
\cline { 2 - 3 } & Pendapenn & Rp 2004.00; & \\
\hline
\end{tabular}

Sumber drri hasil oldarn data pandis pads tolo referensi ikn hizs lokal 2021

\section{Profitability Index}

\section{TABEL PI PADA TOKO GALE GALE OLSHOP}

\begin{tabular}{|c|r|r|c|}
\hline \multirow{2}{*}{$\mathrm{PI}=$} & PV Kas Bersih & Rp 164.015.280 & \multirow{2}{*}{2,18} \\
\cline { 2 - 3 } & Total Investasi & Rp 75.000.000 & \\
\hline
\end{tabular}

Sumber dari Toko Ikan Hias Gale Gale Olshop

\section{TABEL PI PADA TOKO KOPET AQUATIC}

\begin{tabular}{|c|r|r|c|}
\hline \multirow{2}{*}{ PI $=$} & PV Kas Bersih & Rp 141.615.864 & \multirow{2}{*}{2,36} \\
\cline { 2 - 3 } & Total Inveatasi & RP 60.000.000 & \\
\hline
\end{tabular}

Sumber dari Toko Ikan Hias Kopet Aquatic

\section{TABEL PI PAA TOKO KING}

\begin{tabular}{|c|r|r|c|}
\hline \multirow{2}{*}{$\mathrm{PI}=$} & PV Kas Bersih & Rp 95.898.816 & \multirow{2}{*}{2,13} \\
\cline { 2 - 3 } & Total Investasi & Rp 45.000.000 & \\
\hline
\end{tabular}

Sumber dari Toko Ikan Hias King 


\section{TABEL PI PADA TOKO REFERENSI USAHA}

\begin{tabular}{|c|c|c|c|}
\hline \multirow{2}{*}{$\mathrm{I}=$} & DKa Beril & $\mathrm{Rp} 5.165 .964$ & \multirow{2}{*}{2,36} \\
\hline & Total Inetail & Rp2000000 & \\
\hline
\end{tabular}

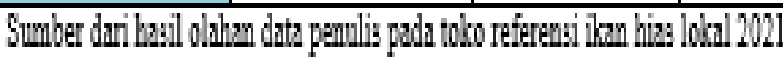

Berikut data analisis kelayakan usaha dari metode-metode yang telah dihitung dan parameternya pada 3 toko ikan hias lokal dan toko referensi usaha ikan hias lokal :

\section{TABEL HASIL ANALISIS KELAYAKAN DAN PARAMETERNYA PADA TOKO GALE GALE OLSHOP}

\begin{tabular}{|c|l|r|r|c|}
\hline No & \multicolumn{1}{|c|}{ Metode Penguluran } & \multicolumn{1}{|c|}{ Hasil } & Parameter & Keterangan \\
\hline 1 & Payback Periode & 0,96 & 3 Talum & LAYAK \\
\hline 2 & Average Rate Of Retum & $97 \%$ & $50 \%$ & LAYAK \\
\hline 3 & Net Present Value & Rp 89.015 .280 & Rp 75.000 .000 & LAYAK \\
\hline 4 & Profitability Index & 2,18 & 1 & LAYAK \\
\hline
\end{tabular}

Sumber dari Toko Ikan Hias Gale Gale Olshop

\section{TABEL HASIL ANALISIS KELAYAKAN DAN PARAMETERNYA PADA TOKO KOPET AQUATIC}

\begin{tabular}{|r|l|r|r|c|}
\hline No & \multicolumn{1}{|c|}{ Metode Pengukuran } & \multicolumn{1}{|c|}{ Hasil } & Parameter & Keterangan \\
\hline 1 & Payback Periode & 0,89 & 3 Tahum & LAYAK \\
\hline 2 & Average Rate Of Retum & $103 \%$ & $50 \%$ & LAYAR \\
\hline 3 & Net Present Value & Rp 81.615 .864 & Rp 60.000 .000 & LAYAK \\
\hline 4 & Profitability Index & 2,36 & 1 & LAYAK \\
\hline
\end{tabular}

Sumber dari Toko Ikan Hias Kopet Aquatic

\section{TABEL HASIL ANALISIS DAN PARAMETERNYA PADA TOKO KING}

\begin{tabular}{|r|l|r|r|c|}
\hline No & \multicolumn{1}{|c|}{ Metode Pengukuran } & \multicolumn{1}{|c|}{ Hasil } & Parameter & Keteraugan \\
\hline 1 & Payback Periode & 0,98 & 3 Talum & LAYAR \\
\hline 2 & Average Rate Of Return & $90 \%$ & $50 \%$ & LAYAR \\
\hline 3 & Net Present Value & Rp 50.898 .816 & Rp 45.000 .000 & LAYAR \\
\hline 4 & Profitability Index & 2,13 & 1 & LAYAR \\
\hline
\end{tabular}

Sumber dari Toko Ikan Hias King

TABEL HASIL ANALISIS DAN PARAMETERNYA PADA TOKO REFERENSI USAHA

\begin{tabular}{|r|l|r|r|c|}
\hline No & Metode Penguluran & \multicolumn{1}{|c|}{ Havil } & Parameter & Keterangan \\
\hline 1 & Payback Periode & $0,8 \mathrm{~B}$ & 3 Tahum & LAYAK \\
\hline 2 & Average Rate Of Return & $92 \%$ & $50 \%$ & LAYAK \\
\hline 3 & Net: Present Value & Rp 34.165.964 & Rp 25000000 & LAYAK \\
\hline 4 & Profitability Inder & 2,36 & 1 & LAYAK \\
\hline
\end{tabular}

Sumber dari hasil obhan data penulis pada toko referensi ina hias lokal 2021 


\section{E. KESIMPULAN DAN SARAN}

\section{1) Kesimpulan}

Kesimpulan yang di dapat dari penelitian mengenai Analisis Studi Kelayakan Bisnis Usaha Ikan Hias Lokal Khas Bangka Belitung di Wilayah Kota Pangkalpinang yaitu :

a. Usaha Ikan Hias sebagai toko referensi layak untuk dijalankan berdasarkan aspek pasar dan pemasaran, karena di wilayah kota Pangkalpinang masih sedikit toko ikan hias yang memasarkan ikan hias lokal. Permintaan akan ikan hias lokal pun sudah banyak dan cukup meningkat setiap bulannya, serta proses produksi untuk memenuhi permintaan pasar pun masih bisa dipenuhi dan dikendalikan, karena untuk pemenuhan permintaan pengusaha melakukan pengembangbiakkan sendiri untuk bibit dan ikan hias lokal yang dipasarkan. Proses pemasaran dan pengenalan tentang ikan hias lokal pun tidak sulit, dibantu memasarkan melalui media online dan media sosial yang sekarang lebih mudah digunakan dan banyak masyarakat yang menggunakan mediamedia tersebut.

b. Usaha ikan hias lokal sebagai toko referensi ditinjau dari aspek teknis pun layak untuk dijalankan. Baik dari segi pemilihan lokasi, skala produksi, teknologi yang digunakan, display bangunan serta sarana dan prasarana yang digunakan sudah cukup memadai dan modern. Pada aspek teknis pun tidak sulit untuk dipenuhi untuk penunjang agar aktivitas dari usaha ikan hias lokal ini beroperasional dengan maksimal.

c. Berdasarkan analisis kelayakan finansial menunjukkan bahwa usaha ikan hias lokal yang menjadi referensi usaha layak untuk dijalankan karena telah memenuhi kriteria investasi diantaranya NPV sebesar Rp 34.165.964;, ARR sebesar $92 \%$, Profitability Indexnya sebesar 2,36 dan Payback Period selama 8 bulan.

\section{2) Saran}

Saran yang ditujukan untuk usaha referensi ikan hias lokal khas Bangka Belitung di wilayah kota Pangkalpinang diantaranya :

a. Dilihat dari aspek pasar dan pemasarannya usaha ikan hias lokal khas Bangka Belitung di wilayah kota Pangkalpinang harus memperhatikan dengan lebih ekstra, baik dari sisi permintaan ataupun penawaran pasar yang meningkat setiap bulan dan tahunnya.

b. Dilihat dari aspek teknis, usaha ikan lokal juga harus mempertimbangkan lokasi usaha dalam memilih dan menjaga lingkungan, baik internal ataupun eksternal usaha karena lingkungan yang baik akan memberikan dampak yang baik juga untuk masa mendatang.

c. Pada aspek finansial, usaha ikan hias lokal sebagai referensi layak untuk dikembangkan, dengan melihat potensi pasar baik dari permintaan dan penawaran pasar yang lumayan meningkat setiap tahunnya. Usaha ini dapat terus dikembangkan dengan terus meningkatkan pemasaran produk dan meningkatkan skala produksi agar mencapai target pemasaran.

d. Usaha ikan hias lokal yang menjadi referensi disarankan membuat catatan penjualan dengan baik, catatan produksi,catatan penjualan, melihat minat dan permintaan yang paling banyak dari konsumen, agar mengetahui peluang pasar kedepannya, agar usaha ini terus berinovasi dan kreatif melakukan perubahan- 
perubahan baru yang membangun untuk meningkatkan pendapatan dan pemasaran.

\section{DAFTAR PUSTAKA}

Husnan,s, Muhammad. (2000). Studi Kelayakan Bisnis. Yogyakarta:Unit Penerbit dan Percetakan AMP YKPN.

Ichsan, Reza Nurul, Lukman Nasution dan Sarman Sinaga. (2019). Studi Kelayakan Bisnis (Business Feasibility Study). CV. Manhaji Medan.

Ma'arif lqbal, Manullang Rizal Ruben \& Astuti Nelly. (2020). Analisis Studi Kelayakan Bisnis Beternak Ayam Potong-Studi Kasus Implementasi Kandang Box.

Manullang, Rizal Ruben. (2014). The 2015 AEC Business Competition, Business Intelligent and Implications for Small Medium Enterprises Competitiveness published at: "Scientific Research Journal (Scirj), Volume II, Issue I, January 2014 Edition, Page 1-8".

Sandu, Sunyoto \& M. Ali Sodik. (2015). Dasar Metodologi Penelitian. Literasi Media Publishing. Sleman Yogyakarta.

Sugiyono. (2016). Metode Penelitian Kuantitatif, Kualitatif dan R\&D. Edisi Kelima. Bandung: PT Alfabeta.

Sugiyono. (2017). Metode Penelitian Kuantitatif, Kualitatif dan $R$ \& D. Edisi Ke-enam. Bandung: ALFABETA. 